\title{
ARTIKKELIT
}

\section{Sähköiset omahoitopalvelut ovat mahdollisuus myös ikääntyville}

\author{
Anna-Stiina Vaahtera ${ }^{1}$, Anna Koskinen ${ }^{1}$ ja Sari Himanen ${ }^{1}$
}

${ }^{1}$ Tampereen ammattikorkeakoulu

\begin{abstract}
Sähköiset omahoitopalvelut tarjoavat kansalaisille välineitä seurata hyvinvointiaan, ehkäistä sairauksien pahenemista ja nopeuttaa tarkoituksenmukaiseen hoitoon pääsyä. Tutkimuksen tarkoituksena oli 2017 toteutetun kyselyn avulla kartoittaa, kuinka hyvin kansalaiset tuntevat ja miten halukkaita he ovat käyttämään sähköisiä terveyspalveluja sekä millaisia näkemyksiä heillä on sähköisistä omahoitopalveluista. Kyselyyn vastasi 165 henkilöä. Vastaajat olivat iältään 19-85-vuotiaita. 56-85-vuotiaita oli $28 \%$, naisia $82 \%$ ja kaupungin työntekijöitä $52 \%$. Vastaajat tunsivat sähköisiä terveyspalveluja hyvin. Vähintään puolet vastaajista käyttäisi todennäköisesti kuvattuja sähköisiä omahoitopalveluja, ja noin puolet arvioi niiden vaikuttavan positiivisesti omasta hyvinvoinnistaan huolehtimiseen. Sähköisten omahoitopalvelujen käyttöön tulisi saada tukea verkossa ja henkilökohtaisesti. Eniten koettiin huolta tietoturvasta ja lisäksi pelättiin kasvokkain tapahtuvien palvelujen vähenemistä. Eriikäisten vastaajien näkemykset eivät eronneet toisistaan merkitsevästi. Sähköisiä terveyspalveluja kannattaa suunnitella myös ikääntyville. Tutkimuksen tulokset toimivat keskustelun herättäjinä ja hyödyttävät palvelujen kehittämisessä, mutta niitä ei suoraan voida yleistää koskemaan kaikkia ikääntyneitä tai kansalaisia yleensä.
\end{abstract}

\section{Johdanto}

Kansalaisten rooli oman terveyden ylläpidossa ja sairauksien hoidossa on korostumassa (Korhonen \& Virtanen 2015) ja sitä kuvataan käsitteellä omahoito (self-management). Omahoito voidaan määritellä potilaan oikeudeksi ja kyvyksi tehdä omaa terveyttään koskevia päätöksiä. (Routasalo, Airaksinen, Mäntyranta \& Pitkälä 2009.) Se sisältää kyvyn selviytyä sairautensa kanssa arjessa sekä taitoja tai keinoja vähentää sairauden aiheuttamia fyysisiä ja psyykkisiä vaikutuksia itse tai yhdessä terveydenhuoltojärjestelmän toimijoiden kanssa (McGowan 2005). Omahoidon tavoitteena on ehkäistä pitkäaikaissairauksien puhkeamista, hidastaa taudin etenemistä, lievittää oireita ja parantaa elämänlaatua (Barley \& Lawson 2016).

Omahoidon tueksi kehitteillä olevien sähköisten palvelujen avulla kansalaiset voivat seurata itse omaa hyvinvointiaan, terveyttään ja sairauksiaan, tehdä erilaisia mittauksia ja seurantaa sekä tallentaa näitä tietojaan turvalliseen terveystietojen hallinta-alustaan. Tällaisesta sähköisestä palvelusta voidaan käyttää nimeä 
henkilökohtainen terveyskertomus, terveystaltio tai terveyskansio. (Seppälä \& Nykänen 2014.) Teknologian ja erilaisten sensorien eli anturien kehittymisen myötä mahdollisuudet oman voinnin ja terveyden seurantaan, mittaamiseen ja tietojen tallentamiseen laajenevat ja helpottuvat (Korhonen \& Virtanen 2015). Kansalaisten itse tallentamat ja ammattilaisten järjestelmistä tulevat tiedot voivat tulevaisuudessa muodostaa tietopohjan automaattiselle päättelylle ja älykkäälle oirearviolle, joiden perusteella asiakas voi saada kotihoito-ohjeita, lähetteitä, reseptejä, kutsuja vastaanotolle tai neuvontaa (Kuntaliitto 2018a). Sähköisten terveystarkastusten ja sairastumisriskiä mittaavien riskitestien avulla asiakas voi saada ehdotuksia elämäntapamuutoksiin (Seppälä \& Nykänen 2014). Omahoitopalvelujen antamat suositukset perustuvat lääketieteelliseen näyttöön ja Duodecimin tuottamaan tietämyskantaan ja algoritmeihin (Duodecim 2018; Kuntaliitto 2018a).

Omahoidon toteutumista on pyritty tukemaan poliittisella ohjauksella. Sote-tieto hyötykäyttöön 2020 -strategian tavoitteena on parantaa kansalaisten mahdollisuutta omaehtoiseen terveydestä ja hyvinvoinnista huolehtimiseen (STM 2014). Palvelut asiakaslähtöisiksi -kärkihankkeen tavoitteena on tukea asiakasta toimintakyvyn ylläpitämisessä ja omahoidossa (STM 2018). Vuonna 2014 käynnistetyn ODA-hankkeen (omahoito ja digitaaliset arvopalvelut) tavoitteena on tuoda yhtenäiset omahoitopalvelut koko Suomeen. Hankkeessa kehitettävä sähköisten terveys- ja hyvinvointipalvelujen Omaolo-palvelukokonaisuus sisältää kolme osiota: Hyvinvointitarkastuksen ja valmennukset, Oire- ja palveluarviot sekä Oma Suunnitelman. (Kuntaliitto 2018a.) Kansalaisilla on jo nyt mahdollisuus päästä joihinkin ammattilaisten käyttämien potilastietojärjestelmien osioihin, joissa on mahdollista esimerkiksi omien tietojen katselu, ajanvaraus ja turvallinen viestinvälitys (Hyppönen, Hyry, Valta \& Ahlgren 2014; Lähteenmäki, Kariniemi \& Vainio 2014; STM 2014).
Virtuaalisairaala 2.0 kehittämishankkeella tavoitellaan Suomen yliopistollisten sairaaloiden palvelujen tuomista jokaiselle suomalaiselle digitaalisin välinein asuinpaikasta riippumatta. Hankkeessa rakennetaan erikoissairaanhoidon verkkopalvelu Terveyskylää, jonka talot tarjoavat kansalaisille tietoa, tukea ja hoitoa. Taloilla on omapolku-palvelukanavia, joille avataan jatkuvasti omahoito-ohjelmia. (Virtuaalisairaala2.fi 2018.)

Sosiaalihuollon sähköisten palvelujen kehittäminen on terveydenhuoltoa jäljessä. Erityisesti ikäihmisille niitä on tarjolla vain vähän ja paikallisesti. Joissain palveluissa hyödynnetään helppokäyttötoimintoja, kuten tekstin suurennusta tai muuttamista puheeksi. (Kauppila, Kiiski \& Lehtonen 2018.) Ikäihmisten kotona asumisen tukena on hyödynnetty erilaisia seuranta-, hälytys- sekä yhteydenpitovälineitä (Mäkisalo-Ropponen 2017). Esimerkiksi turvarannekkeeseen integroituun älykelloon (muun muassa Vivago Care) voidaan liittää aktiivisuusseurantaa, uniaikaa ja muun muassa kulunvalvontaa mittaavia ominaisuuksia (Vivago.fi 2018). Etäseurantalaitteiden mittaama tieto saadaan tällä hetkellä siirtymään hoidosta vastaavalle taholle ja tulevaisuudessa nämä mittaustulokset voitaisiin ehkä liittää osaksi henkilökohtaista sähköistä terveyskertomusta (Korhonen \& Virtanen 2015).

Ammattilaisen päätöksenteon tueksi kehitetty Suuntima on erilaisten asiakasryhmien tunnistamisen työkalu. Sen avulla terveydenhuollon asiakas ja ammattilainen voivat yhdessä suunnitella asiakkaalle sopivan hoitopolun. (TAYS 2017; Suuntima 2018.) Sähköisten henkilötietojen luotettava ja turvallinen käsittely pyritään turvaamaan tietoturvapolitiikalla, joka Kelalla, terveydenhuollon organisaatioilla ja apteekeilla on muun muassa Kanta-palvelun käyttöä varten. Jokaisen tietojen käyttäjän henkilöllisyys varmistetaan vahvaa sähköistä tunnistusta käyttäen ja kaikesta Kanta-palvelujen käytöstä jää jälki, jota kutsutaan lokitiedoksi. Tämä on yksi tapa valvoa järjestelmän käyttöä. (Kansaneläkelaitos 2018.) Henkilötietosuojaa 
parantamaan on asetettu uusi EU:n henkilötietojen käsittelyä koskeva tietosuoja-asetus (EU 2016/679), joka tuli voimaan toukokuussa 2018. Sillä pyritään vahvistamaan yksilön oikeuksia, ohjaamaan ja yhdenmukaistamaan henkilötietojen käsittelyä ja tehostamaan tietosuojasääntöjen valvontaa.

Internetissä olevien sähköisten palvelujen saavutettavuus on Suomessa periaatteessa hyvä. Alle 55-vuotiaista lähes kaikki ( $\geq 99 \%$ ) olivat käyttäneet internetiä vuonna 2016. Ikäihmisilläkin internetin käyttö lisääntyy nopeasti. Kun vuonna 2016 oli internetiä käyttänyt 75-89-vuotiaista $31 \%$, oli vuotta myöhemmin luku jo 37 \%. (Tilastokeskus 2016; Tilastokeskus 2017.) Sivustojen esteettömyys on sähköisissä terveyspalveluissa olennaista, jotta sivustojen selailu onnistuu ikäihmisiltäkin. Yleisten teknistä käytettävyyttä ja hyväksyttävyyttä määrittelevien kriteerien mukaan sovellusten tulisi olla helposti opittavissa ja käyttöönotettavissa, toimintalogiikan helposti muistettavissa, ohjelmassa ei saisi olla bugeja eli virheitä ja lisäksi ohjelman käyttöliittymän tulisi olla sellainen, että käyttö voidaan kokea miellyttäväksi (Nielsen 1993).

\section{Iäkkäiden valmiudet sähköisten terveyspalvelujen käyttöön}

Rosenlund ja Kinnunen $(2018,264,273)$ toteavat, että iäkkäiden kokemukset sähköisten palvelujen käytöstä ovat pääosin myönteisiä. Suurin hyöty tietotekniikasta ja sähköisistä palveluista saadaan, kun ikäihmiset osallistetaan kehittämistyöhön sen eri vaiheissa. Useiden tutkimusten mukaan heikot tietotekniset käyttötaidot ja epäusko omaa osaamista kohtaan onkin tunnistettu tekijöiksi, jotka ovat vaikeuttaneet sähköisten terveyspalvelujen käyttöä iäkkäillä (esim. Stub Petersen, Bertelsen \& Tornbjerg 2015; Sakaguchi-Tang, Bosold, Choi \& Turner 2017). Lamin ja hänen tutkimusryhmänsä mukaan (2013) ikä ei kuitenkaan ole este sähköisten palvelujen käytölle.
Iäkkäät tarvitsevat uusien palvelujen käyttöönotossa nuorempia enemmän tukea (Hyppönen ym. 2014,). Tässä auttaa sekä perheen tuki, että terveydenhuollon palveluntuottajien antama ohjaus (esim. Sakaguchi-Tang ym. 2017).

Zarcadoolas, Vaughon, Czaja \& Rockoff (2013) havaitsivat, että ikäihmiset eivät pitäneet omiin potilastietoihinsa pääsyä lähtökohtaisesti lainkaan tärkeänä, mutta suurin osa muutti näkemystään kokeiltuaan terveyskansion käyttöä käytännössä. Krist ym. (2014) ovat tehneet samansuuntaisen havainnon: iäkkäät käyttivät terveyskansiota todennäköisemmin silloin, kun sen käyttöönottoa tuettiin suunnitelmallisesti. Sähköisessä viestinvälityksessä ikäihmisten on todettu arvostavan ammattilaisten rohkaisua, ohjausta, käyttäjäystävällistä ohjelmaa ja toimivuutta (Archer, FevrierThomas, Lokker, McKibbon \& Straus 2011; Lam ym. 2013; Irizarry ym. 2017) sekä muun muassa lääkärin sitoutumista käyttämään ohjelmaa asiakkaan kanssa (Lam ym. 2013). Iäkkäiden on tunnistettu epäilevän, toteutuuko tarpeellinen hoito, jos henkilökohtainen tapaaminen korvataan sähköisellä palvelulla. Tietoturvan toteutumisen on havaittu huolettavan enemmän keski-ikäisiä kuin nuorempia tai vanhempia henkilöitä. (Hyppönen ym. 2014; Stub Petersen ym. 2015.)

Suomalaisen valtakunnallisen vuonna 2014 tehdyn kartoituksen mukaan alle 50-vuotiaat käyttivät sähköisiä terveyspalveluja tai terveyskansiota aktiivisimmin ja yli 65-vuotiaat vähiten. Ikäluokka 50-65-vuotiaat näyttäytyivät vedenjakajana nuorempien ja vanhempien ikäryhmien välillä. Tähän ikäluokkaan kuuluvat olivat kiinnostuneita oman terveydentilansa seurannasta ja hoitosuunnitelman laatimisesta sähköisesti. (Hyppönen ym. 2014.) He muodostavat siten potentiaalisen tulevaisuuden käyttäjäryhmän. Iän ohella koulutustaustalla on useissa tutkimuksissa havaittu olevan yhteys sähköisten terveyspalvelujen käyttöön siten, että korkeasti koulutetut ovat kiinnostuneempia seuraamaan terveystietojaan verkossa ja käyttämään sähköistä yhteystapaa ter- 
veyspalveluissa asioidessaan vähemmän koulutettuihin verrattuna (esim. Emani ym. 2012; Hyppönen ym. 2014; Stub Petersen ym. 2015). Suomessa korkeasti koulutettujen osuus työikäisestä väestöstä on maailmanlaajuisesti korkea (Kalenius 2014), mikä näin ollen ennustaa, että valmiudet sähköisten palvelujen käyttöön olisivat Suomessa hyvät.

Sähköisten omahoitoportaalien avulla voidaan helpottaa huoltajien tai omaishoitajien roolia (Tang, Ash, Bates, Overhage \& Sands 2006). Toisen puolesta asiointi, tiedon etsiminen ja palautteen antaminen sähköisesti olivat Hyppösen ja hänen tutkimusryhmänsä (2014, 38, 41) mukaan Suomessa yleisiä sähköisten palvelujen käyttötapoja sekä iäkkäiden että alaikäisten huoltajilla. Useat ikäihmiset toivovat omien tietojen käyttöoikeutta läheisille. Esimerkiksi tanskalaisen tutkimuksen mukaan enemmistö yli 70-vuotiaista toivoi läheisilleen mahdollisuutta asioida heidän puolestaan. (Stub Petersen ym. 2015.)

\section{Sähköisten omahoitopalvelujen mahdollisuudet}

Omahoitopalveluista asiakkaat pääsevät näkemään terveystietojaan nopeasti, mikä voi tukea ymmärryksen saamista omasta tilanteesta. Tämän myötä ongelmien puheeksi ottaminen ammattilaisten kanssa voi toteutua nopeammin. (Esim. Tang ym. 2006; Hyppönen ym. 2014; Stub Petersen ym. 2015.) Helposti saatavilla olevat tiedot helpottavat tiedon muistamista ja tietojen oikeellisuuden varmistamista, minkä myötä väärinymmärrykset ja virheet vähenevät (Zarcadoolas ym. 2013; Hyppönen ym. 2014; Stub Petersen ym. 2015). Kahn, Aulakh ja Bosworth (2009) toteavat, että terveyskansion hyödyntäminen voi parantaa ammattilaisen ja asiakkaan välistä kumppanuutta ja yhteistyötä. Se voi myös lisätä turvallisuudentunnetta ja motivaatiota terveyskäyttäytymisen muutokseen sekä hoitoon ja lääkitykseen sitoutumiseen (esim. Tang ym. 2006; Chrischilles ym. 2013; Hyppönen ym. 2014; Stub Petersen ym. 2015; Young \& Nesbitt 2017).

Asiakkaiden itse raportoimat tiedot ja etäseurantalaitteiden tuottamat tulokset mahdollistivat oletettavasti paremman lääketieteellisen päätöksenteon ja vaihtoehtoisten hoitokeinojen arvioinnin (Nagykaldi ym. 2010; Kuijpers ym. 2014). Ne mahdollistavat myös systemaattisemman ja objektiivisemman potilasohjauksen (esim. Tang ym. 2006; Krist ym. 2011). Risling, Martinez, Young ja Thorp-Froslien (2017) mukaan näyttö potilasportaalien vaikutuksesta potilaan voimaantumiseen on kuitenkin vielä heikkoa ja vaatii lisätutkimusta.

Potilasportaalien ja sähköisten palvelujen käytöllä tavoitellaan ajan säästämistä ja joustavuutta, ja ammattilaisten ajankäytön tarkoituksenmukaista kohdentamista (Tang ym. 2006; Aaltonen ym. 2009; Hyppönen ym. 2014; Stub Petersen ym. 2015). Miellyttäväksi ja helppokäyttöiseksi koetun omahoitosovelluksen uskotaan vähentävän terveydenhuollon vastaanottokustannuksia (Velardo ym. 2017). Sähköisen asioinnin avulla voisi Hyppösen ym. $(2014,43)$ mukaan Suomessa saada aikaan jopa 1,6 miljoonan tunnin säästön, mikä on rahaksi mitattuna 30 miljoonaa euroa. Kehitystrendillä on siis selkeä kansantaloudellinen merkitys.

Väestön ikääntyminen ja elinajanodotteen pidentyminen merkitsevät hyvinvointivaltiolle haasteita, joiden ratkaisemiseen tarvitaan uusia keinoja (Valtioneuvosto 2018). Sähköiset omahoitopalvelut tulevat olemaan yksi ratkaisu tähän. Niiden kehittäminen on juuri nyt ajankohtaista eri puolilla maailmaa, ja Suomessakin niitä on kehitteillä sekä kansallisesti (Omaolopalvelukokonaisuus ja Virtuaalisairaalan omapolku-ohjelmat) että yksityisten palveluntuottajien toimesta. Käyttökokemukset niistä ovat toistaiseksi melko vähäisiä, mistä syystä etenkin suomalaista tutkimustietoa on toistaiseksi melko vähän. Tähänastisen tutkimustiedon perusteella sähköisten palvelujen tuottama lisäarvo ja hyöty ovat lisänneet halukkuutta palvelujen käyttöönottoon ja niihin sitoutumiseen. Tutkimustietoa tarvitaan sekä stimuloimaan 
sähköisten terveyspalvelujen kehittämistyötä, että tuomaan niitä tunnetuksi niin tulevien maakuntien sosiaali- ja terveyspalveluista päättäville tahoille kuin kansalaisillekin.

\section{Tutkimustehtävät}

Tutkimuksen tarkoituksena oli kartoittaa erään kaupungin asukkaiden näkemyksiä sähköisistä terveyspalveluista. Tutkimuskysymykset olivat:

1. Miten tuttuja jo käytössä olevat sähköiset terveyspalvelut ovat vastaajille?

2. Mitä sähköisiä Omaolo-palvelukokonaisuuteen sisältyviä omahoitopalveluja vastaajat todennäköisesti käyttäisivät?

3. Miten vastaajat arvioivat sähköisten omahoitopalvelujen käytön vaikuttavan omasta hyvinvoinnista huolehtimiseen?

4. Millaisia näkemyksiä vastaajilla on sähköisten omahoitopalvelujen eduista ja haasteista?

Tutkimuksen tavoitteena oli tuottaa tietoa, jota voidaan hyödyntää sähköisiä palveluja kehitettäessä ja käyttöönotettaessa. Tutkimuksen avulla pyrittiin samalla myös tekemään sähköisiä palveluja tunnetuksi kansalaisille.

\section{Aineisto ja menetelmät}

Tutkimuksen kohderyhmänä oli pienehkön kaupungin asukkaat $(\mathrm{N}=33$ 000). Aineisto kerättiin sähköisellä ja paperisella, itse laaditulla strukturoidulla kyselylomakkeella, keväällä 2017. Tutkijoilla ei ollut pääsyä kaupungin perusjoukkoa edustaviin rekistereihin, kuten asukas- tai asiakasrekistereihin, joten linkki sähköiseen kyselyyn oli kaupungin kotisivuilla. Tutkimuksen toimeksiantajan toiveesta linkki lähetettiin sähköpostitse kaupungin työntekijöiden esimiehille, joita kehotettiin välittämään linkkiä eteenpäin. Kyselyä mainostettiin Facebook-sivuilla ja paikallislehdessä.
Vastauskuorilla varustettuja paperisia kyselylomakkeita oli useita kymmeniä jaossa terveyskeskuksen kolmella aluevastaanotolla, laboratoriossa ja päivystyksessä sekä muissa julkisissa tiloissa kuten kirjastossa, virasto- ja kaupungintalolla ja uimahallissa. Seinämainoksia ja mainoslipukkeita oli paperilomakkeiden jakelupaikoissa ja kaupan ilmoitustaululla. Mainoksissa ja paperilomakkeissa oli lisäksi kyselyn verkkoosoite ja QR-koodi. Kysely oli saatavilla vain suomen kielellä.

\section{Kyselylomake}

Kyselylomake sisälsi kahdeksan taustatietoja kartoittavaa kysymystä. Niillä kartoitettiin vastaajien sukupuoli, ikä, asema kaupungissa (asukas/työntekijä) ja työelämässä, koulutus, pitkäaikaissairaudet, terveyspalvelujen käyttömäärä ja onko käytössä internet tai sähköiset asiointitunnukset.

Varsinaisten kysymysten aihealueiksi valittiin ODA-hankkeessa kehitettäviä omahoitopalveluja ja tutkimuksen kohteena olevassa kaupungissa käytössä tai kehitteillä olevia sähköisiä terveyspalveluja. Ensimmäisellä seitsemänkohtaisella kysymysosiolla kartoitettiin jo käytössä olevien sähköisten terveyspalvelujen tunnettavuutta. Vastausvaihtoehdot olivat 1 = en ole kuullut, 2 = olen kuullut ja 3 = olen käyttänyt. Toisessa kysymysosiossa kuvattiin lyhyesti kuusi Suomessa käytössä tai kehitteillä olevaa sähköistä omahoitopalvelua ja kysyttiin vastaajan todennäköisyyttä palvelun käyttöön Likert-asteikollisilla vastausvaihtoehdoilla 1-5 niin, että vaihtoehto 1 = erittäin epätodennäköisesti ja 5 = erittäin todennäköisesti. Vaihtoehtona oli myös $0=$ en osaa sanoa.

Kolmannessa kysymysosiossa kartoitettiin vastaajien näkemystä siitä, millainen yhteys sähköisten terveyspalvelujen käytöllä on omasta hyvinvoinnista huolehtimiseen. Neljännessä ja viidennessä kysymysosiossa oli sähköisiin omahoitopalveluihin liittyviä etuja ja haasteita kuvaavia väittämiä. Vastaajien samanmielisyyttä niihin kartoitettiin Likert-asteikollisilla vas- 
tausvaihtoehdoilla. Näiden väittämien muodostamisessa otettiin huomioon aiemmissa tutkimuksissa havaittuja omahoitoportaalien käyttöön liittyviä taustatekijöitä, vaikutuksia, etuja ja haasteita. Lomakkeen lopussa oli avoin kysymys, jolla sai antaa palautetta kyselystä.

Kyselylomake esitestattiin kymmenellä henkilöllä, jotka edustivat taustatekijöiltään erilaisia kansalaisia. Esitestaukseen osallistuvilta pyydettiin kirjallinen ja suullinen palaute. Esitestauksen perusteella muutamaa sanamuotoa hiottiin ja kyselyyn lisättiin yksi väittämä.

\section{Aineiston käsittely ja analyysi}

Paperilomakkeilla saadut vastaukset yhdistettiin sähköisellä kyselylomakkeella kerättyyn aineistoon. Taustamuuttujia luokiteltiin analysointia varten. Ikä luokiteltiin kolmeen suunnilleen saman suuruiseen luokkaan (1939-, 40-55- ja 56-85-vuotiaat). Koulutustausta luokiteltiin kahteen luokkaan (korkeakoulututkinnon suorittaneet ja alemmin koulutetut). Koska joko alemman tai ylemmän korkeakoulututkinnon suorittaneita oli lähes puolet vastaajista, yhdistettiin muut eli perusasteen, toisen asteen ja opistoasteen suorittaneet luokaksi Alemmin koulutetut. Asema työelämässä luokiteltiin kahteen luokkaan. Eläkeläisiä, työttömiä ja opiskelijoita oli niin vähän, että ne yhdistettiin luokaksi Työelämän ulkopuolella olevat.

Analysointivaiheessa Likert-asteikollisia vastausvaihtoehtoja luokiteltiin. Toisen kysymysosion vastausvaihtoehdoissa epätodennäköisesti palveluja käyttäviksi laskettiin vaihtoehdot 1 (erittäin epätodennäköisesti) ja 2 (epätodennäköisesti) valinneet ja todennäköisesti käyttäviksi ne, jotka olivat vastanneet vaihtoehdon 4 (todennäköisesti) tai 5 (erittäin todennäköisesti). Vastaajien saman mielisyyttä kartoittavien kysymysten kohdalla väittämän kanssa eri mieltä oleviksi laskettiin vaihtoehdot 1 (täysin eri mieltä) ja 2 (eri mieltä) valinneet ja samaa mieltä oleviksi ne, jotka olivat vastanneet vaihtoehdon 4 (samaa mieltä) tai
5 (täysin samaa mieltä). Tuloksia kuvattaessa prosentit on pyöristetty lähimpään tasalukuun.

Aineisto analysoitiin SPSS 23 -ohjelmalla. Aineistosta otettiin suoria jakaumia. Taustamuuttujien yhteyttä tutkittaviin asioihin tarkasteltiin ristiintaulukoinnilla ja khiin neliö -testillä sekä Spearmanin korrelaatiotestillä. Muuttujien välisiä yhteyksiä tarkasteltiin Pearsonin korrelaatiotestillä. Yleisimmin käytetyt merkitsevyystasot ovat tilastollisesti erittäin merkitsevä $p \leq 0,001$, tilastollisesti merkitsevä $\mathrm{p} \leq 0,010$ ja tilastollisesti melkein merkitsevä $\mathrm{p} \leq 0,050$. (Heikkilä 2014, 185, 192-195.) Korrelaatiokerrointa tulkittiin Metsämuurosen (2009, 371) mukaan niin, että korrelaatiokerroin välillä 0,8 -1 on erittäin korkea, välillä 0,6 0,8 korkea ja välillä 0,4-0,6 melko korkea tai kohtuullinen.

\section{Tutkimuksen eettisyys}

Tutkimuksessa noudatettiin Tutkimuseettisen neuvottelukunnan (2012) hyvän tieteellisen käytännön ohjeita. Aiempien tutkijoiden oikeuksia kunnioitettiin ja tutkimuksen raportoinnissa noudatettiin tarkkuutta ja huolellisuutta.

Tutkimuslupa saatiin kohteena olevan kaupungin hoitotyön johtajalta. Tutkimukseen vastaaminen oli vapaaehtoista ja se toteutui anonyymisti. Sekä sähköisen, että paperisen kyselylomakkeen saatekirjeessä kuvattiin tutkimuksen tarkoitus ja tavoite sekä mistä tutkimustulokset ovat luettavissa. Sähköinen kysely toteutui linkin kautta, josta ei kerätty tunnistetietoja. Paperiset vastaukset palautuivat nimettömänä vastauskuoressa korkeakoululle. Aineisto säilytettiin asianmukaisesti ulkopuolisten ulottumattomissa.

Tutkimuksen tavoitteena oli tuottaa tietoa sähköisten palvelujen kehittämiseen ja tuoda niitä kaupunkilaisille tunnetuksi. Siten tutkimus voi osaltaan olla edistämässä terveyttä, terveydenhuollon ammattilaisten eettisen ohjeiston tavoitteen mukaisesti (Etene 2001, 4). 


\section{Tulokset}

Kyselyyn vastasi 165 henkilöä, joista enemmistö oli naisia (82\%). Vastaajat olivat iältään 19-85-vuotiaita. Vastaajista 22 oli eläkeikäisiä (yli 65-vuotiaita). Lähes puolella vastaajista oli korkeakoulututkinto ja lähes kaikilla sähköiset asiointitunnukset. Yksi tai useampi pitkäaikaissairaus oli lähes puolella vastaajista, samoin terveyspalveluissa käyntejä korkeintaan kolme vuodessa. Yhden tai useamman pitkäaikaissairauden olemassaolo oli merkitsevästi yhteydessä vastaajien ikäluokkiin $(r=0,412$ ja $\mathrm{p}=0,000)$. Taustatekijöiden välillä ei löytynyt muita merkitseviä yhteyksiä. Puolet vastaajista (52\%) oli kaupungin työntekijöitä, mutta kos- ka osa heistä oli myös kaupungin asukkaita, ei näiden luokkien vastauksia verrattu keskenään. (Taulukko 1.)

Vastaajat tunsivat kysytyt sähköiset omahoitopalvelut hyvin, lukuun ottamatta Suuntimaa. Enemmistö vastaajista oli myös käyttänyt useita kysytyistä palveluista. (Taulukko 2.) Sähköisten riskitestien käyttö oli tilastollisesti erittäin merkitsevästi $(p=0,001)$ yleisempää keski-ikäisillä ja nuoremmilla kuin vanhimman ikäluokan vastaajilla. Muilla taustatekijöillä ei ollut lineaarista yhteyttä kysyttyihin asioihin.

Vastaajia pyydettiin arvioimaan, kuinka todennäköisesti he käyttäisivät muun muassa Omaolo-palvelukokonaisuuteen sisältyviä säh-

Taulukko 1. Vastaajien $(n=165)$ taustatiedot.

Koulutustaso

Asema työelämässä

Sairastavuus

Terveyspalvelujen käyttömäärä

Internetyhteys

Sähköiset asiointitunnukset

\begin{tabular}{|c|c|c|}
\hline & lukumäärä & $\%$ \\
\hline nainen & 135 & 82 \\
\hline mies & 30 & 18 \\
\hline $19-39 v$ & 52 & 31 \\
\hline $40-55 \mathrm{v}$ & 67 & 41 \\
\hline $56-85 \mathrm{v}$ & 46 & 28 \\
\hline korkeakoulututkinto & 80 & 48 \\
\hline alemmin koulutetut & 84 & 51 \\
\hline ei vastausta & 1 & 1 \\
\hline työelämässä & 132 & 80 \\
\hline työelämän ulkopuolella & 33 & 20 \\
\hline $\begin{array}{l}\text { yksi tai useampi lääkärin } \\
\text { toteama pitkäaikaissairaus }\end{array}$ & 77 & 47 \\
\hline ei pitkäaikaissairautta & 86 & 52 \\
\hline en osaa sanoa & 2 & 1 \\
\hline o-3 kertaa vuodessa & 91 & 55 \\
\hline 4-9 kertaa vuodessa & 57 & 35 \\
\hline$\geq 10$ kertaa vuodessa & 17 & 10 \\
\hline kyllä & 158 & 96 \\
\hline ei & 7 & 4 \\
\hline kyllä & 160 & 97 \\
\hline ei & 5 & 3 \\
\hline
\end{tabular}


Taulukko 2. Sähköisten terveyspalvelujen tunteminen $(n=165)$ *

\begin{tabular}{l|ccc}
\multicolumn{1}{l|}{} & $\begin{array}{c}\text { En ole } \\
\text { kuullut }\end{array}$ & $\begin{array}{c}\text { Olen } \\
\text { kuullut }\end{array}$ & $\begin{array}{c}\text { Olen } \\
\text { käyttänyt }\end{array}$ \\
\hline $\begin{array}{l}\text { Verkkoajanvaraus } \\
\begin{array}{l}\text { Potilastietojen } \\
\text { katsominen verkossa }\end{array}\end{array}$ & $3 \%$ & $20 \%$ & $77 \%$ \\
$\begin{array}{l}\text { Omakanta } \\
\text { Etävastaanotto }\end{array}$ & $2 \%$ & $24 \%$ & $73 \%$ \\
Sähköinen resepti & $4 \%$ & $19 \%$ & $76 \%$ \\
Riskitestit & $10 \%$ & $75 \%$ & $5 \%$ \\
Suuntima & $19 \%$ & $5 \%$ & $94 \%$ \\
\end{tabular}

*prosentit pyöristetty lähimpään tasalukuun

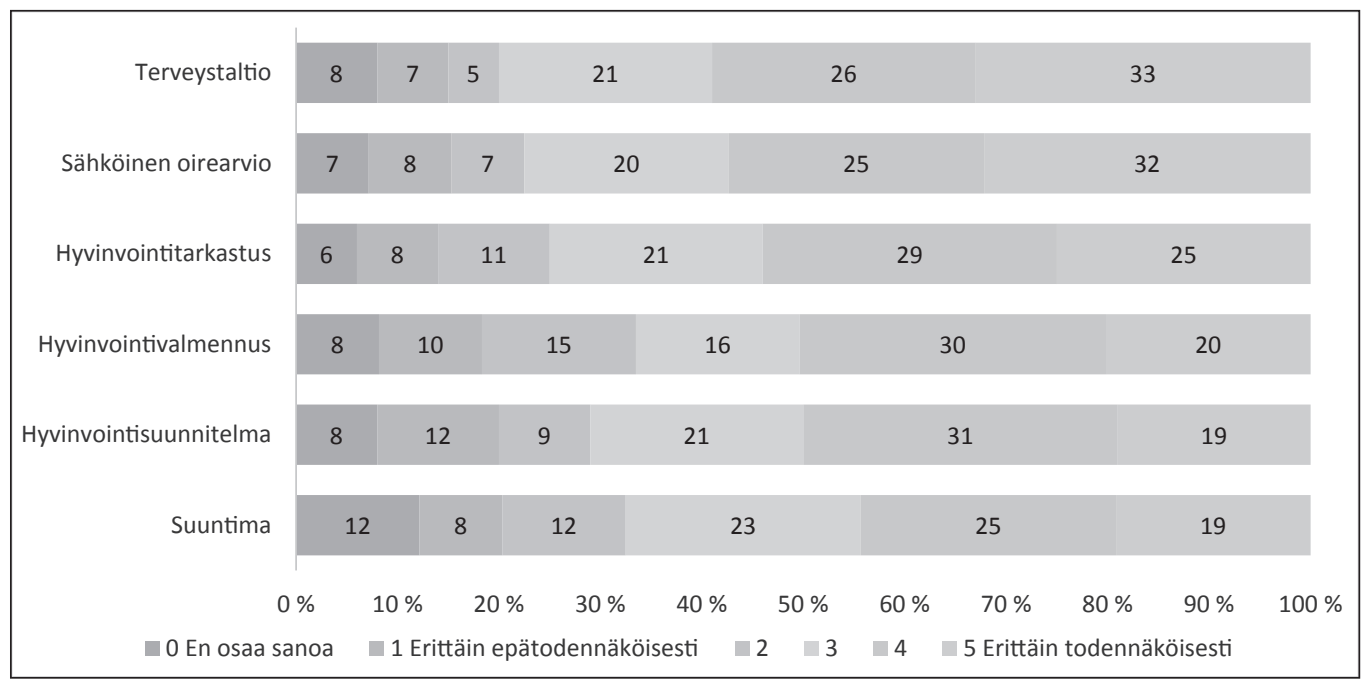

Kuvio 1. Vastaajien (n=165) todennäköisyys käyttää sähköisiä omahoitopalveluja.

köisiä omahoitopalveluja, jotka oli kysymyksen yhteydessä määritelty lyhyesti. Vähintään puolet vastaajista voisi todennäköisesti käyttää kaikkia muita kysyttyjä palveluja lukuun ottamatta Suuntimaa, jota todennäköisesti käyttäisi $44 \%$ vastaajista. Hyvinvointivalmennuksesta kysyttäessä $25 \%$ vastaajista arvioi, että sen käyttö olisi epätodennäköistä. Jokaisen väittämän kohdalla vähintään neljäsosa vastaajista ei osannut ottaa kantaa palvelun käyttämisen todennäköisyyteen, vastaten kysymykseen joko "En osaa sanoa" tai valiten arvon 3 (ei samaa eikä eri mieltä). (Kuvio 1.) Palvelujen käyttä- misen todennäköisyys ei eronnut merkitsevästi eri ikäluokkien vastausten välillä, eikä myöskään muiden taustamuuttujien välillä.

Yli puolet vastaajista arvioi, että edellisessä kysymyksessä kuvattujen sähköisten palvelujen käyttö voisi lisätä heidän motivaatiotaan edistää terveyttä ja hyvinvointia (54 \%) tai lisätä heidän motivaatiotaan mahdollisen sairauden hoitoon (52\%). Lähes puolet (46\%) vastaajista arvioi, että kuvatut palvelut voisivat alentaa heidän kynnystään hakeutua tarvittaessa sosiaali- tai terveydenhuollon piiriin. Noin kolmannes ei ilmaissut selkeää kantaa tämän 
Sähköiset palvelut voisivat lisätä motivatiotani edistää omaa terveyttäni ja hyvintointiani

Sähköiset palvelut voisivat lisätä motivaatiotani liittyen mahdollisen sairauteni hoitoon

Sähköiset palvelut voisivat alentaa kynnystäni hakeutua tarvittaessa sosiaali- tai terveydenhuollon piiriin

\begin{tabular}{|c|c|c|c|c|c|}
\hline 10 & 8 & 10 & 19 & 32 & 22 \\
\hline 8 & 8 & 9 & 24 & 31 & 21 \\
\hline 10 & 8 & 15 & 21 & 30 & 16 \\
\hline
\end{tabular}

$0 \% 10 \% 20 \% 30 \% 40 \% 50 \% 60 \% 70 \% 80 \% 90 \% 100 \%$ 口 En osaa sanoa $\square 1$ Täysin eri mieltä $\square 2 \quad \square 3 \square 4 \quad \square 5$ Täysin samaa mieltä

Kuvio 2. Vastaajien (n=165) näkemykset säbköisten palvelujen käytön yhteydestä omasta hyvinvoinnista huolehtimiseen.

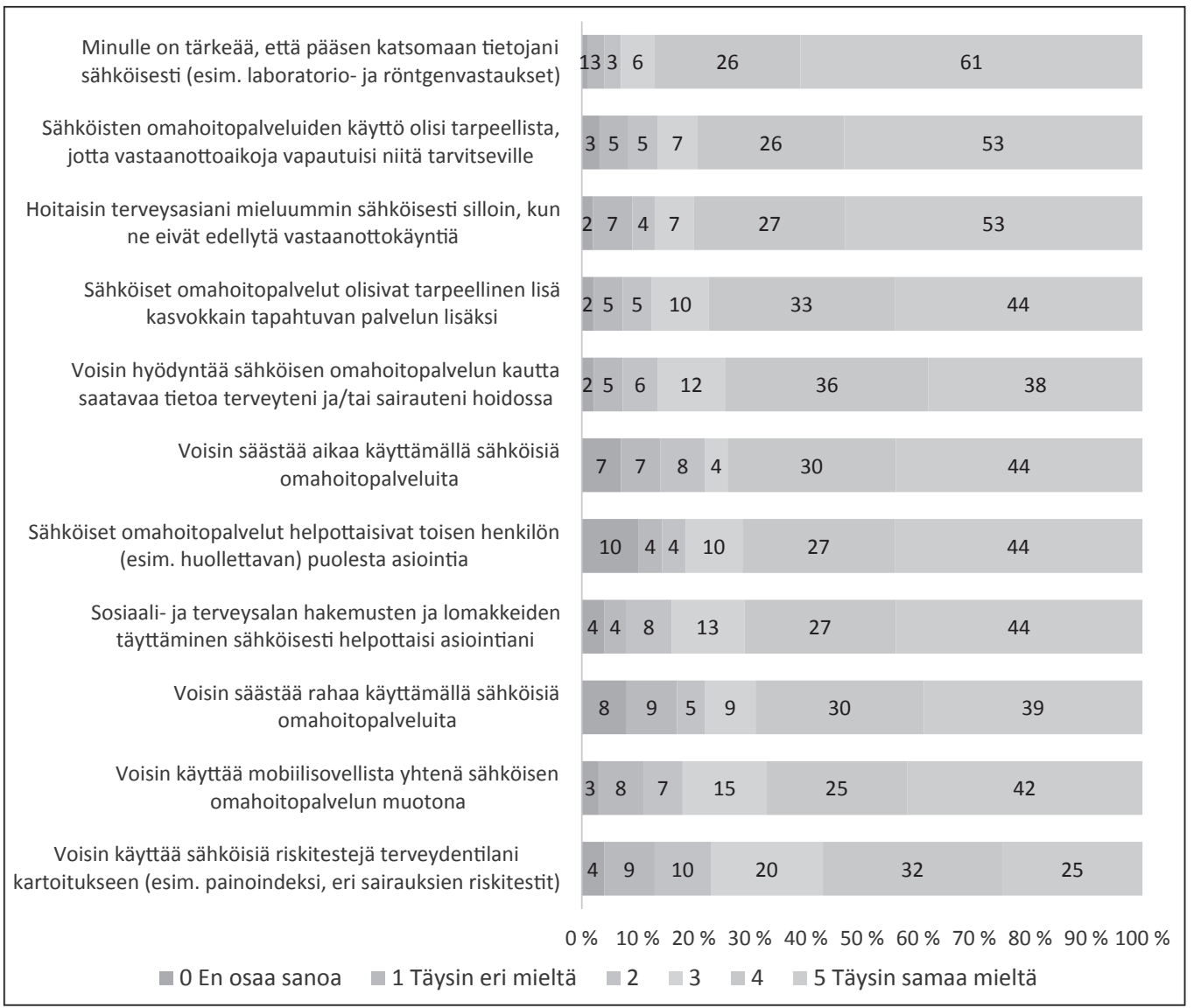

Kuvio 3. Vastaajien (n=165) näkemykset säbköisten palvelujen käytön tuomista eduista. 
osion kysymyksiin (vastaukset $0=$ en osaa sanoa tai vastaus 3 = ei samaa eikä eri mieltä). Vastaajien ikäluokilla tai muilla taustatekijöillä ei ollut tilastollisesti merkitsevää lineaarista yhteyttä kysyttyihin väittämiin. (Kuvio 2.)

Vastaajille esitettiin 12 sähköisten palvelujen käytön tuomaa etua kuvaavaa väittämää ja yli puolet vastaajista oli samaa mieltä kaikkien väittämien kanssa. Vähintään 80 \% vastaajista koki tärkeänä, että pääsee katsomaan omia terveystietojaan sähköisesti ja hoitaisi terveysasiat mieluummin sähköisesti silloin, jos asia ei edellytä vastaanottokäyntiä. Vastaajista $79 \%$ puolsi näkemystä, että sähköisten palvelujen käyttö on tarpeellista, jotta vastaanottoaikoja vapautuu niitä tarvitseville. Lomakkeiden täyttäminen, toisen puolesta asiointi, ajan ja rahan säästyminen olivat sähköisten palvelujen tuomia etuja vastaajista kahden kolmasosan mielestä. Vastaajien ikäluokilla tai muilla taustatekijöil- lä ei ollut tilastollisesti merkitsevää lineaarista yhteyttä kysyttyihin väittämiin. (Kuvio 3.)

Vastaajille esitettiin kahdeksan väittämää, jossa kuvattiin sähköisten palvelujen käyttöön mahdollisesti liittyviä haasteita, ja kysyttiin heidän näkemystään niihin. Neljä viidesosaa vastaajista oli samaa mieltä siitä, että sähköisten palvelujen käyttöön tulisi saada käyttötukea sekä palvelun verkkosivuilta, että tarvittaessa henkilökohtaisesti. Hieman yli puolet vastaajista (55\%) vastasi pelkäävänsä, että sähköisten palvelujen lisääminen vähentää kasvokkain toteutuvan palvelujen tarjontaa. $13 \%$ vastasi, että ei halua asioida sähköisesti, ja $12 \%$ vastasi pelkäävänsä, ettei osaa käyttää sähköisiä palveluja. Tietoturva arvelutti kolmasosaa (35\%) vastaajista. Vastaajien ikäluokilla tai muilla taustatekijöillä ei ollut tilastollisesti merkitsevää lineaarista yhteyttä kysyttyihin väittämiin. (Kuvio 4.)

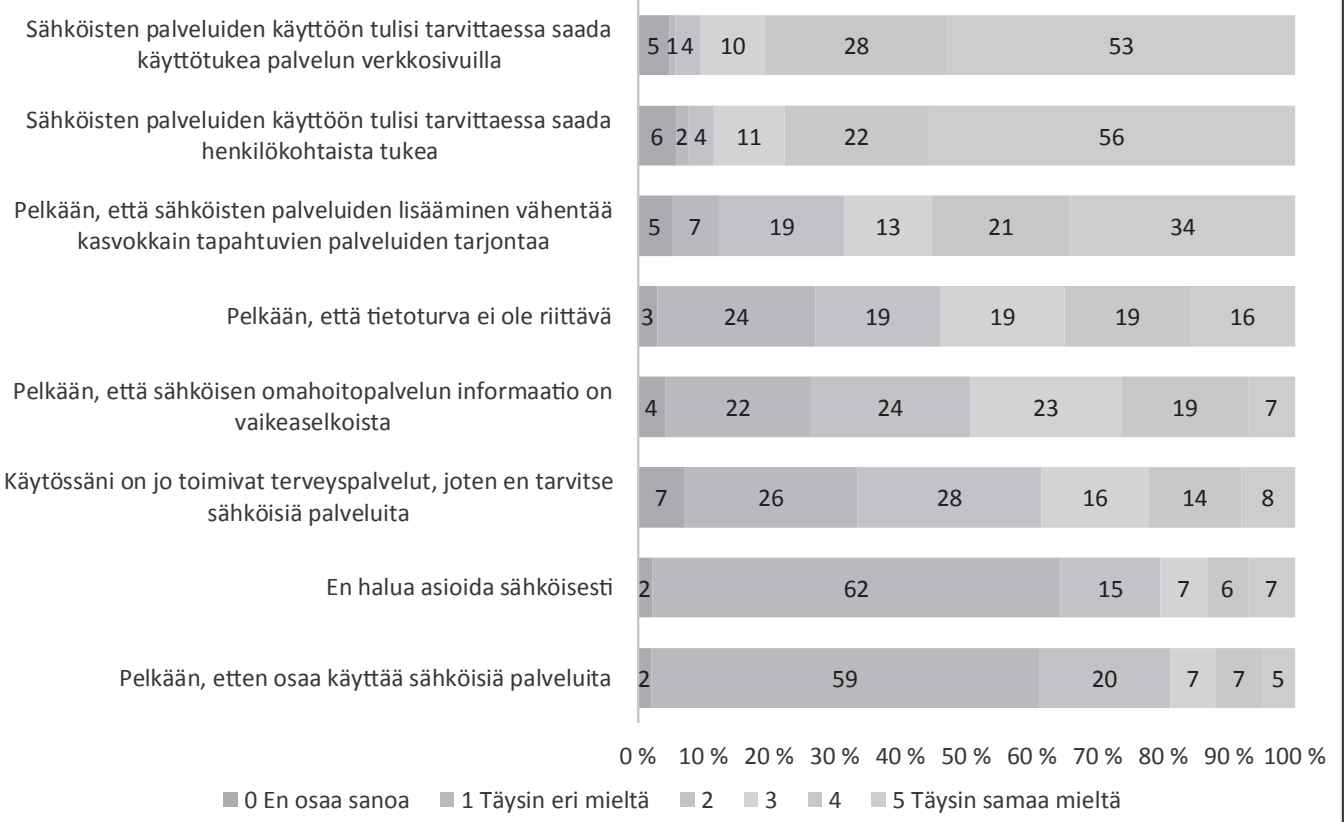

Kuvio 4. Vastaajien (n=165) näkemykset säbköisten palvelujen käyttöön liittyvistä haasteista. 


\section{Pohdinta}

\section{Tulosten tarkastelu}

Tämän tutkimuksen tuloksissa eri ikäisten vastaajien näkemykset sähköisiä omahoitopalveluja kohtaan eivät merkitsevästi eronneet toisistaan. Täten voidaan ajatella, että ikä ei välttämättä ole merkittävä sähköisten terveyspalveluiden käyttöhalukkuuteen yhteydessä oleva tekijä. Vastaajien taustatekijöiden välisiä yhteyksiä tutkittaessa havaittiin, että vanhempiin ikäluokkiin kuuluvilla oli yksi tai useampi pitkäaikaissairaus useammin kuin nuorempaan ikäluokkaan kuuluvilla, mikä ennustaa, että vanhempiin ikäluokkiin kuuluvilla terveyspalvelujen kysyntä on suurempaa kuin nuoremmilla. Sähköisiä terveyspalveluja ja niiden käyttöä tukevia toimia kannattaa siis kehittää erityisesti ikäihmisten tarpeita vastaaviksi. Kuten Lam ym. (2013) ovat todenneet, ikä ei ole este sähköiselle asioinnille, sillä iäkkäätkin ihmiset ovat halukkaita käyttämään sähköisiä kommunikaation välineitä, jos heillä on niistä aiempaa kokemusta.

Vastaajista 94 \% vastasi kyselyyn sähköisesti ja vain seitsemän vastaajaa (4 \%) täytti paperisen kyselylomakkeen. Tämä voisi kuvastaa myönteistä asennetta sähköisten välineiden käyttöä kohtaan. Toisaalta vastaajajoukko ei kuvaa kaupunkilaisia yleisellä tasolla erityisesti siksi, että kysely lähetettiin sähköisesti osalle kaupungin työntekijöistä. Kyselyssä kuvatut sähköiset palvelut olivat vastaajille pääosin tuttuja. Suurin osa oli käyttänyt niistä useita, kuten sähköistä reseptiä, verkkoajanvarausta ja katsonut asiakastietojaan verkossa. Valtakunnalliseen Hyppösen ja tutkimusryhmänsä $(2014,74)$ kartoitukseen verrattaessa tulos oli odotettava: suomalaisilla oli hyvät valmiudet sähköisten palvelujen käyttöön jo vuonna 2014.

Etävastaanotosta oli kuullut kolme neljäsosaa vastaajista, ja kahdeksan oli käyttänyt sitä. Tämä on palvelumuoto, joka tulee lähivuosina oletettavasti lisääntymään.
Etävastaanottotoiminnan kehittäminen luo mahdollisuuksia terveyspalvelujen järjestämiseen uudella ja kustannustehokkaalla tavalla. Timosen (2004) mukaan kolme neljäsosaa perusterveydenhuollon asiakkaista voidaan hoitaa etätyönä. Etäyhteyden mahdollistava tekniikka on varsin kehittynyttä ja sitä voidaan toteuttaa joko puhelinpalveluna, kuvapuhelinyhteydellä, tai reaaliaikaisena eli välittömästi tapahtuvana pikaviesti- eli chat-palveluna. Joissakin kunnissa asukkaille lainataan kuvapuhelinyhteyden mahdollistava laitteisto, jolla esimerkiksi kotihoidon asiakkaat voivat olla yhteydessä ammattilaisiin (Nykänen, Savela \& Kiviniemi 2017).

Sähköiset asiointitunnukset olivat kolmea vastaajaa lukuun ottamatta kaikilla, mikä on ymmärrettävää, sillä Suomessa ne ovat tulleet suurelle osalle kansasta jo tutuiksi muun muassa pankki- ja vakuutusasioinnissa. Hyppösen tutkimusryhmän vuonna 2014 saamien tutkimustulosten mukaan sähköisten asiointitunnusten puuttuminen oli yhteydessä yli 65-vuoden ikään, huonoksi koettuun terveydentilaan ja kroonisten sairauksien olemassaoloon. Toisaalta taas joidenkin tutkimusten mukaan huonoksi koetulla terveydentilalla, kroonisella sairaudella ja suurella terveyspalvelujen käyttöasteella on havaittu olevan positiivinen yhteys sähköisten terveyspalvelujen käyttämiseen ja sähköisen asioinnin arvostamiseen (esim. Archer ym. 2011; Hyppönen ym. 2014; Stub Petersen ym. 2015). On myös mahdollista, että terveytensä ylläpidosta ylipäätään kiinnostuneet ovat kiinnostuneita myös sähköisten terveyspalvelujen käytöstä (Archer ym. 2011, 520; Tenforde ym. 2011), eikä tämä suhtautuminen välttämättä ole ikäriippuvaista. Potilasportaalien käyttämisen todennäköisyys voikin liittyä taustatekijöitä enemmän internetin käyttöön liittyvään osaamiseen (Woods ym. 2017), tai kokemukseen sähköisten palvelujen hyödyllisyydestä (Emani ym. 2012). Ikääntyneiden ihmisten todennäköisyyteen käyttää potilasportaalia vaikuttaa oletettavasti myös mahdollisuudet saada tukea tietotek- 
nisten laitteiden ja sähköisten palvelujen käyttöönottamiseen (Sakaguchi-Tang ym. 2017).

ODA-hankkeessa kehitettävä sähköinen Omaolo-palvelukokonaisuus on syksyllä 2018 edennyt testausvaiheeseen (Kuntaliitto 2018b). Jatkossa Omaolon kehittämisestä ja kansallisesta levittämisestä vastaa valtion omistama kehitysyhtiö SoteDigi (SoteDigi 2018). Tähän tutkimukseen vastanneiden mukaan aika kansalliselle levittämiselle näyttäisi olevan otollinen, sillä vastaajista vähintään puolet arvioi todennäköisesti käyttävänsä palvelukokonaisuuteen kuuluvia sähköistä oirearviota, hyvinvointitarkastusta, -valmennusta ja -suunnitelmaa.

Omahoidolla tavoitellaan terveempää elämää, eli pitkäaikaissairauksien puhkeamisen ehkäisyä, sairauksien hitaampaa etenemistä, oireiden lievittymistä ja parempaa elämänlaatua (mm. Barley \& Lawson 2016). Tähän tutkimukseen osallistuneiden vastaukset tukivat osaltaan tämän tavoitteen oletusta, sillä vastaajista noin puolet arvioi, että kyselyssä kuvatut sähköiset omahoitopalvelut voisivat lisätä heidän motivaatiotaan edistää omaa terveyttään ja hyvinvointiaan sekä hoitaa mahdollista sairauttaan. Tulos vahvistaa aiempaa tutkimustietoa siitä, että sähköiset omahoitopalvelut voisivat voimaannuttaa käyttäjiä ottamaan vastuuta omasta terveydestään ja hyvinvoinnistaan (esim. Archer ym. 2011; Ong, Jassal, Porter, Logan, \& Miller 2013). Terveydenhuollossa nähtävissä oleva maailmanlaajuinen suuntaus korostaa kansalaisten roolia terveyden ylläpidossa ja myös sairauksien hoidossa. Erilaisten hyvinvointia mittaavien ja tukevien laitteiden ja sovellusten määrä ja käyttö kansalaisilla lisääntyvät, ja ne tulisi saada integroitua entistä paremmin osaksi ammattilaisten käyttämiä asiakastietojärjestelmiä, mikä tukisi kokonaisvaltaista yksilön terveydentilan dokumentointia. (Korhonen \& Virtanen 2015.) Esimerkiksi elintoimintoja monitoroivia älyrannekkeita voisi lainata ikäihmisille, ja laiteinvestoinnista aiheutuneet kulut saattaisivat tulla takaisin akuuttivastaanottokäyntien vähenemisenä ja hallitumpana sairauksien hoitona. Jo käytös- sä olevien turvarannekkeiden tuottamaa tietoa kannattaisi opetella myös hyödyntämään entistä enemmän. Seppälän ja Nykäsen (2014, 24 26) mukaan uusien toimintamallien tuomien muutosten tulisi näkyä ammattilaisten arjessa, ja heitä tulisi opastaa niiden käyttöön. Tämä merkinnee henkilökunnalle lisäkoulutuksen tarvetta ja uudenlaista rekisteröityneen tiedon ohjaamaa työotetta.

Tähän tutkimukseen vastanneista $87 \%$ piti tärkeänä päästä katsomaan omia terveystietojaan sähköisesti. Tämä mahdollisuus lisää kansalaisten tasa-arvoa, palvelujen esteettömyyttä ja läpinäkyvyyttä sekä tehostaa ammattilaisten ajankäyttöä, kun tulosten ja tietojen tiedusteluihin ei kulu puhelinaikaa. Omien terveystietojen katsomiseen liittyy lääketieteellisen tekstin ymmärtämiseen liittyvät haasteet, mikä edellyttäisi jonkinlaisen avun järjestämistä tekstien ja termien tulkintaan (Lyles, Fruchterman, Youdelman \& Schillinger 2017). Myös tutkimustulosten tulkinnan on tunnistettu huolettavan asiakkaita, mikäli tulokset poikkeavat viitearvoista (Zarcadoolas ym. 2013). Näihin tilanteisiin toivotaan lääkärin kannanottoa perusteluineen.

Vastaajista $71 \%$ arvioi sähköisten omahoitopalvelujen helpottavan toisen puolesta asiointia, mikä on arvokas apu esimerkiksi huoltajan tai omaishoitajan roolissa (Tang ym. 2006). Pääsy läheisen potilastietoihin on tunnistettu yhdeksi keskeiseksi kehittämisen kohteeksi sekä Lylesin ym. (2017) mukaan että Hyppösen tutkimusryhmän (2014) tutkimuksessa, jossa toisen puolesta asioinnille havaittiin tarpeita erityisesti ajanvarauksissa, reseptilääkkeiden hankinnassa, palvelutarjoajien etsinnässä ja yhteydenpidossa hoitavaan tahoon. Tietoturvan riittävyys on kysymys, mikä on sähköisen asioinnin yhteydessä noussut esiin useissa tutkimuksissa (esim. Kahn ym. 2009; Zarcadoolas ym. 2013; Hyppönen ym. 2014) ja se edellyttää huolellista suostumus- ja lupakäytäntöjen tarkastelua. Tietoturva huoletti kolmasosaa tämän tutkimuksen vastaajista. 
Vaikka vastaajat suhtautuivat pääasiallisesti myönteisesti kaikkiin kuvattuihin sähköisiin palveluihin, ne herättivät jonkin verran myös pelkoja. Vastaajista hieman yli puolet pelkäsi, että kasvokkain tapahtuvat palvelut heikkenevät sähköisten palvelujen yleistyessä. Tähän saattaa liittyä myös pelkoa siitä, että ammattilaiset käyttäisivät tietotekniikkaan enemmän aikaa kuin hoitoon, eikä potilas saa perusteellista hoitoa, ellei tapaa ammattilaista kasvokkain (Stub Petersen ym. 2015). Neljäsosa pelkäsi, että sähköisen omahoitopalvelun informaatio on vaikeaselkoista, ja kymmenesosa pelkäsi, ettei osaa käyttää sähköisiä palveluja. Sähköisiä palveluja tulisikin kehittää ajatellen niitä ryhmiä, jotka todennäköisimmin niitä tarvitsevat ja käyttävät (Hyppönen ym. 2014; Bauer ym. 2017). Samoin tulisi huomioida erilaiset ihmisryhmät sekä käyttäjien erilaiset kognitiiviset kyvyt (esim. Archer ym. 2011; Czaja ym. 2014).

Enemmistö vastaajista oli sitä mieltä, että sähköisten palvelujen käyttöön tulisi saada tukea sekä sähköisesti että henkilökohtaisena palveluna. Kansalaisten todellinen tuen tarve saattaa olla tätäkin suurempi, sillä tässä tutkimuksessa korkeakoulutettujen osuus oli suurempi kuin väestössä keskimäärin. Lisäksi vastaajajoukkoon valikoitui paljon kaupungin työntekijöitä, koska heille lähetettiin sähköisesti linkki kyselylomakkeeseen. Tuen tarve on tunnistettu useassa aiemmissakin tutkimuksessa (esim. Hyppönen, livari \& Ahopelto, 2011; Krist ym. 2014; Lyles ym. 2017; SakaguchiTang ym. 2017), ja siihen panostamista ei varmaankaan liikaa voi korostaa sähköisten palvelujen käyttöönoton yhteydessä.

Usein esitetty olettamus on, että sähköiset palvelut saattavat lisätä iäkkäämpien kansalaisten eriarvoisuutta, mikä on otettava huomioon jo palvelujen ja niiden käyttöön liittyvien tukitoimien suunnittelussa (Czaja ym. 2014; Hyppönen ym. 2014; Bauer ym. 2017). Yksi tukimuoto on verkkosivustojen chat-palvelu, mikä monissa sähköisissä palveluissa on jo käytössä. Henkilökohtaisen tuen tarjoamiseen olisi myös hyvä resursoida henkilökuntaa paitsi sosiaali- ja terveydenhuollon yksiköihin, myös jalkautumaan julkisiin paikkoihin kuten virastoihin ja kauppakeskuksiin, sekä esimerkiksi ikäihmisten asumisyksiköihin. Kohteena olleessa kaupungissa toimii jo sosiaali- ja terveyspalvelujen ohjausta ja neuvontaa antava hyvinvointikioski, joka neuvoo myös sähköisten palvelujen käytössä.

Suuntima-palvelu ei ollut tähän tutkimukseen osallistuneille vastaajille tuttu, mutta heistä $44 \%$ voisi todennäköisesti käyttää sopivan asiakkuuspolun tunnistamiseen kehitettyä Suuntimaa, jos sille tulisi tarvetta. Palvelujärjestelmiä uudistettaessa Suuntima saattaisi olla oiva apu, jonka avulla hoitoprosessit voisivat tulla joustavammiksi ja palvelun tuottajien turha kuormittuminen voisi vähentyä. Suuntiman käyttö aloitetaan esimerkiksi sairaanhoitajan vastaanotolla, eikä sen käyttöönotto ole täten kiinni asiakkaasta, vaan ammattilaisesta. Ammattilaisten innostus ja rohkaisu sekä koetut hyödyt lisäävät todennäköisyyttä omaksua sähköisen terveyspalvelujen käyttöä (Emani ym. 2012). Suuntima on täten yksi väline, jonka avulla ammattilaiset voisivat tukea ja ohjata ikäihmisiä sähköisen asioinnin pariin.

\section{Tutkimuksen luotettavuus}

Tutkimuksessa on monia puutteita. Aineiston keruu toteutui itse laaditulla kyselylomakkeella, jolla saatiin haluttuja tietoja, joten sen sisältövaliditeetti voidaan arvioida kohtuullisen hyväksi. Validiteetilla tarkoitetaan mittarin, eli kyselylomakkeen pätevyyttä mitata juuri sitä, mitä sen on tarkoitus mitata (KvantiMOTV 2008). Kaksi vastaajaa kuvasi kyselylomakkeen lopussa avoimeen kysymykseen vastatessaan kysymyksiä osittain johdatteleviksi, mutta toisaalta kolme vastaajaa kuvasi kysymyksiä hyvin muotoilluksi, selkeiksi ja kokonaisuutta hallituksi. Kaksi vastaajaa kuvasi lomaketta liian 
pitkäksi, mikä on saattanut aiheuttaa keskittymisen herpaantumista kyselyyn vastattaessa.

Aineiston keruu toteutui kohteena olevassa kaupungissa satunnaisella otannalla, koska asukasrekisteriä ei ollut käytettävissä. Kyselyyn on saattanut vastata tutkittavan aiheen kannalta valikoitunut joukko eli terveyden edistämisestä tai sähköisistä palveluista kiinnostuneita. Paperisia lomakkeita palautui vain seitsemän, mikä voi kuvata sitä, että perinteisiä menetelmiä priorisoivat eivät ole vastanneet. Vastaajista puolet (52\%) oli kaupungin työntekijöitä, mitä selitti se, että kysely lähetettiin sähköisesti osalle kaupungin työntekijöistä, riippuen siitä, välittikö esimies kyselyä eteenpäin. Vastaajista valtaosa (82 \%) oli naisia, joten tuloksia ei voi yleistää miehiin, vaikka toisaalta useiden aiempien tutkimusten mukaan miehet ovat naisia kiinnostuneempia tietotekniikan käytöstä yleensä (Volman \& van Eck 2001). Lähes puolella vastaajista (48\%) oli korkeakoulututkinto, mikä edustaa tämän päivän tilannetta melko hyvin, sillä korkeakoulututkinnon suorittaneiden osuus 25-64-vuotiaiden ikäluokissa oli Suomessa 43 \% vuonna 2016 (OECD 2017, 50). Valikoituneen aineiston tutkimustuloksia ei voida yleistää (Heikkilä 2014, 178).

Tutkimuksen vastaajajoukko oli pienehkö $(n=165)$ ja rajoitti tulosten analysointia. Hyvin pienten tai erikokoisten ryhmien vertaaminen keskenään ei anna mielekkäitä tai luotettavia tuloksia (Heikkilä 2014, 75). Osa vastauksista jakaantui taustatekijöiden perusteella niin pieniin ryhmiin, ettei ristiintaulukointia voitu tehdä. Tulokset kuvataan pääasiassa luokiteltuina suorina jakaumina ja tuloksia on havainnollistettu kuvioilla ja taulukoilla. Näyte antaa tietoa aineistoon valikoituneiden vastaajien näkemyksistä ja tuloksia voidaan pitää erityisesti yhteiskunnallista keskustelua herättävinä ja palvelujen kehittämistyötä stimuloivina.

\section{Johtopäätökset}

Suurella osalla kansalaisista on internetyhteys ja sähköiset asiointitunnukset, joten lähtökohdat Omaolo-palvelukokonaisuuden käyttöönotolle ovat hyvät. Tähän tutkimukseen vastanneet tunsivat sähköiset terveyspalvelut hyvin ja suhtautuivat niiden käyttöön myönteisesti. Tutkimus ei kuitenkaan ole yleistettävissä, sillä kyseessä on itse mukaan ilmoittautuneet asukkaat ja työntekijät, eikä edustava otos kaupungin asukkaista. Tutkimukseen osallistuneen vanhimman ikäluokan, paljon terveyspalveluja käyttävien sekä pitkäaikaissairaiden näkemykset eivät merkitsevästi eroa muista vastaajaryhmistä. Näin ollen he käyttävät ja kokevat sähköisistä palveluista hyötyä yhtä todennäköisesti kuin muutkin vastaajat. Vaikka tämän tutkimuksen vastaajaryhmä ei aineiston valikoituneisuuden takia ole yleistettävissä koko väestöön, tämä voi antaa viitteitä siitä, että sähköisten terveyspalvelujen käyttöönottoa kannattaa tietoisesti suunnata myös ikäihmisille ja pitkäaikaissairaille.

Sähköisten palvelujen käyttöönotossa tarvitaan markkinointia, kannustusta ja tukea, ja näiden suunnittelussa ja toteuttamisessa kannattaa hyödyntää innovatiivisia menetelmiä sekä esimerkiksi vapaaehtoistyöntekijöitä ja sosiaali- ja terveysalan opiskelijatyövoimaa. Sähköisten omahoitopalvelujen avulla ajatellaan voitavan tukea itsenäistä arjessa selviytymistä, ja yhtenä jatkotutkimushaasteena olisikin kartoittaa ammattilaisten näkemyksiä tästä oletuksesta. Ammattilaisten asenteet ovat tässäkin asiassa keskiössä, koska heillä on tärkeä rooli uusien palvelujen ja työtapojen käyttöönotossa.

\section{Yhteydenotto:}

Anna-Stiina Vaahtera, sh YAMK

Sähköposti: a.vaahtera@gmail.com 


\section{Kirjallisuus}

Aaltonen, A., Ailio, A., Kilpikivi, P., Nykänen, P., Nyberg, P., Kunnamo, I., Kuosmanen, P., Reijonsaari, K. \& Wiesenthal, A. (2009). Kansallisen tason potilastietojärjestelmien toteuttamisvaibtoehtojen vertailu. SITRAn raportti 12.

Archer, N., Fevrier-Thomas, U., Lokker, C., McKibbon, K. \& Straus, S. (2011). Personal health records: a scoping review. A Scholary Journal of Informatics in Health and Biomedicine, 18 (4), 515522.

Barley, E. \& Lawson, V. (2016). Health psychology: supporting the self-management of long-term conditions. British Journal of Nursing, Vol 25, no 20, 1102-1107

Bauer, A., Rue, T., Munson, S., Ghomi, R., Keppel, G., Cole, A., Baldvin, L. \& Katon, W. (2017).Patient-oriented health technologies: Patient's perspectives and use. Journal of Mobile Technology in Medicine, Aug; 6(2), 1-10

Chrischilles, EA., Hourcade, JP., Doucette, W., Eichmann, D., Gryzlak, B., Lorentzen, R., Wright, K., Letuchy, E., Mueller, M., Farris, K. \& Levy, B. (2013). Personal health records: a randomized trial of effects on elder medication safety. Journal of the American Medical Informatics Association, Jul, 21(4), 679-686.

Czaja, SJ., Zarcadoolas, C., Vaughon, WL., Lee, CC., Rockoff, ML. \& Levy, J. (2014). The usability of electronic personal health record systems for an underserved adult population. Human Factors: The Journal of the human factors and ergonomics society, Vol 57, issue 3.

Duodecim (2018). Omat digiajan hyvinvointipalvelut (ODA) ja Omaolo-palvelut. Luettu 11.2.2018. https://www.duodecim.fi/tuotteet-ja-palvelut/ omat-digiajan-hyvinvointipalvelut-oda-ja-omaolo-palvelut/

Emani, S., Yamin, C., Peters, E., Karson, A., Lipsitz, S., Wald, J., Williams, D. \& Bates, D. (2012). Patient perceptions of a personal health record: A test of the diffusion innovation model. Journal of Medical Internet Research, 14(6), e150.

Etene Valtakunnallinen terveydenhuollon eettinen neuvottelukunta (2001). Terveydenhuollon ybteinen arvopohja, ybteiset tavoitteet ja periaatteet. Helsinki: Sosiaali- ja terveysministeriö.

EU 2016/679. Euroopan parlamentin ja neuvoston asetus. https://eur-lex.europa.eu/
Heikkilä, T. (2014). Tilastollinen tutkimus. 9., uudistettu painos. Porvoo: Edita Publishing Oy

Hyppönen, H., Hyry, J., Valta, K. \& Ahlgren, S. (2014). Sosiaali- ja terveydenhuollon säbköinen asiointi. Kansalaisten kokemukset ja tarpeet. Raportti 33/2014. Terveyden ja hyvinvoinnin laitos. http://urn.fi/URN:ISBN:978-952-302-410-6

Hyppönen, H., Iivari, A. \& Ahopelto, M. (2011). Sosiaali- ja terveydenhuollon sähköisen asioinnin hankkeet Suomessa 2010. Terveyden ja hyvinvoinnin laitoksen raportti 31/2011. Tampere: THL. http://urn.fi/URN:NBN:fi-fe201205085350

Irizarry, T., Shoemake, J., Nilsen, M.L., Czaja, S., Beach, S. \& DeVito Dabbs, A. (2017). Patient Portals as a Tool for Health Care Engagement: A Mixed-Method Study of Older Adults With Varying Levels of Health Literacy and Prior Patient Portal Use. Journal of Medical Internet Research, Mar 19(3), e99.

Kahn, J., Aulakh, V. \& Bosworth, A. (2009). What it takes: characteristics of the ideal personal health record. Health Affairs, vol. 28, no. 2, 369-376.

Kalenius, A. (2014). Suomalaisten koulutusrakenne ja sen kehittyminen kansainvälisessä vertailussa. Opetus- ja kulttuuriministeriön julkaisuja 2014:17.2., korjattu painos. Opetus- ja kulttuuriministeriö. http://urn.fi/URN:ISBN:978-952-263-321-7

Kansaneläkelaitos (2018). https://www.kanta.fi/tietosuoja.

Kauppila, T., Kiiski, K., Lehtonen, M. (2018). Säbköhelmenkalastus. Sosiaalibuollon säbköisten palvelujen nykytila ja kehittämistarpeet. Sosiaali- ja terveysministeriön raportteja ja muistioita 14/2018. Helsinki: STM. http://urn.fi/URN:ISBN:978-952-00-3914-1

Korhonen, M. \& Virtanen, T. (2015). Digitaalisuus ja asiakaslähtöisyys sosiaali- ja terveydenhuollossa. Finnish Journal on eHealth and eWelfare, Vol 7, No 4.

Krist, A., Peele, E., Woolf, S., Rothemich, S., Loomis, J., Longo, D. \& Kuzel, A. (2011). Designing a patient-centered personal health record to promote preventive care. BMC Medical Informatics and Decision Making, 11:73.

Krist, A., Woolf, S., Ghalib, B., Sabo, R., Longo, D., Kashiri, P., Etz, R., Loomis, J., Rothemich, S., Peele, E. \& Cohn, J. (2014). Engaging Primary Care Patients to Use a Patient Centered Personal Health Record. Annals of family Medicine, Vol. 12, no. 5 . 
Kuijpers, W., Groen, W., Loos, R., Oldenburg, H., Wouters, M., Aaronson, N. \& Hertern, W. (2014). An interactive portal to empower cancer survivors: a qualitative study on user expectations. Support Care Cancer, 23, 2535-2542.

Kuntaliitto (2018a). ODA-projektin kautta sosiaalija terveyspalvelut loikkaavat digiloikan. Luettu 29.1.2018 https://www.kuntaliitto.fi/asiantuntijapalvelut/sosiaali-ja-terveysasiat/akusti/akusti-projektit/oda

Kuntaliitto (2018b). ODA-projektin kautta sosiaalija terveyspalvelut loikkaavat digiloikan. Luettu 25.9.2018 https://www.kuntaliitto.fi/asiantuntijapalvelut/sosiaali-ja-terveysasiat/akusti/akusti-projektit/oda

KvantiMOTV Kvantitatiivisten menetelmien tietovaranto (2008). Mittaaminen: mittarin luotettavuus. Luettu 6.9.2018. http://www.fsd.uta.fi/menetelmaopetus/mittaaminen/luotettavuus.html

Lam, R., Lin, V., Senelick, W., Tran, H-P, Moore, A. \& Koretz, B. (2013). Older adult consumers' attitudes and preferences on electronic patient-physician messaging. American Journal of Managed Care, 19(10 0 0), eSP7-S11.

Lyles, C., Fruchterman, J., Youdelman, M. \& Schillinger, D. (2017). Legal, Practical, and Ethical Considerations for Making Online Patient Portals Accessible for All. American Journal of Public Health, Vol 107, No 10, 1608-1611.

Lähteenmäki, J., Kariniemi J. \& Vainio, K. (2014). Kuntien säbköisten omahoito- ja asiointipalveluiden arkkitehtuuri. Versio 1.0 / 9.2.2014. https://www. innokyla.fi/documents/712964/a651c1ff-69c844e0-83a2-63ee1e891b00

McGowan, P. (2005). Self management: a background paper. New Perspectives: International Conference on Patient Self-Management. University of Victoria: Centre on Aging.

Metsämuuronen, J. (2009). Tutkimuksen tekemisen perusteet ihmistieteissä. 4.laitos, 1. painos. Jyväskylä: International Methelp $\mathrm{Oy}$.

Mäkisalo-Ropponen, M. (2017). Teknologia yleistyminen hoito- ja hoivatyössä - uhka vai mahdollisuus. Teoksessa Kauppi, P., Kärnä, E., Pihlainen, K. \& Koskela T. (toim.), Teknologia ikäimisen tukena-ketterän kokeilukulttuurin ytimessä. Joensuu: IkäOTe - Ikääntyvien oppiminen ja hyvinvointiteknologiat -hanke.

http://urn.fi/URN:ISBN:978-952-61-2410-0

Nagykaldi, Z., Calmbach, W., DeAlleaume, L., Temte, J., Mold, J. \& Ryan, J. (2010). Facilitating pa- tient self-management through telephony and web technologies in seasonal influenza. Informatics in Primary Care, 18, 9-16.

Nielsen, J. (1993). Usability Engineerings. Boston, MS: Academic Press.

Nykänen, J., Savela, A. \& Kiviniemi T. (2017). Kotihoidon muuttuva työ - teknologia mukana muutoksessa. Teoksessa Kauppi, P., Kärnä, E., Pihlainen, K. \& Koskela T. (toim.), Teknologia ikäimisen tukena - ketterän kokeilukulttuurin ytimessä. Joensuu: IkäOTe - Ikääntyvien oppiminen ja hyvinvointiteknologiat -hanke.

http://urn.fi/URN:ISBN:978-952-61-2410-0

OECD (2017). Education at a Glance 2017: OECD Indicators. Paris: OECD Publishing. http://dx. doi.org/10.1787/eag-2017-en

Ong, S., Jassal, S., Porter, E., Logan, A. \& Miller J. (2013). Using an Electronic Self-Management Tool to Support Patients with Chronic Kidney Disease (CKD): A CKD Clinic Self-Care Model. Seminars in Dialysis, Vol 26, No 2, 195-202

Risling, T., Martinez, J., Young, J. \& Thorp-Froslie, N. (2017). Evaluating Patient Empowerment in Association With e-Health Technology: Scoping Review. Journal of Medical Internet Research, Sep 29, 19(9), e329.

Rosenlund, M. \& Kinnunen, U-M. (2018). Ikäihmisten kokemukset terveydenhuollon sähköisten palvelujen käytöstä ja kokemusten hyödyntäminen palvelujen kehittämisessä - kuvaileva kirjallisuuskatsaus. Finnish Journal of eHealth and eWelfare, 10 (2-3), 264-284.

Routasalo, P., Airaksinen, M., Mäntyranta, T. \& Pitkälä, K. (2009). Potilaan omahoidon tukeminen. Duodecim, 125 (21), 2351-2359.

Sakaguchi-Tang, D.K., Bosold, A.L., Choi Y.K. \& Turner A.M. (2017). Patient Portal Use and Experience Omong Older Adults: Systematic Review. Journal of Medical Internet Research, Oct 16;5(4), e38

Seppälä, A. \& Nykänen, P. (2014). Suomalaisten omahoito- ja terveystaltioratkaisujen tarkastelua kansallisen kehityksen näkökulmasta. Tampereen yliopisto. Informaatiotieteiden yksikön raportteja 32/2014.

SoteDigi (2018). Hallituksen kärkihankkeessa kehitetty Omaolo siirtyy SoteDigille. Luettu 8.11.2018.

https://sotedigi.fi/2018/09/07/hallituksen-karkihankkeessa-kehitetty-omaolo-siirtyy-sotedigille/ STM (2014). Tieto hyvinvoinnin ja uudistuvien pal- 
velujen tukena - Sote-tieto hyötykäyttöon - strategia 2020. Tampere: Sosiaali- ja terveysministeriö, Kuntaliitto.

http://urn.fi/URN:ISBN:978-952-00-3548-8

STM (2018). Tavoitteena jokaiselle palveluja ajasta ja paikasta riippumatta. Luettu 4.9.2018. https://stm.fi/hankkeet/asiakaslahtoisyys/hankkeen-kuvaus

Stub Petersen, L., Bertelsen, P. \& Tornbjerg, K. (2015). Undersogelse af borgernes perspektiv på sundheds-it i 2015 - en udforskning af danskernes kendskab, holdninger, anvendelse og forhold til it til gavn for eget helbred. Dansk Center for Sundhedsinformatik, DaCHI. Aalborg Universitet, september 2015. Technical Report No. 16-3.

Suuntima (2018). Hämeenmaan Sydänpiiri. Luettu 16.4.2018. https://www.suuntima.com/

Tang, P. Ash, J., Bates, D., Overhage, J.M. \& Sands, D. (2006). Personal health records: definitions, benefits, and strategies for overcoming barriers to adoption. Journal of American Medical Informatics Assosiation, 13(2), 121-126.

TAYS (2017). Suunta Suuntimasta kohti arjessa pärjäämistä. Luettu 24.4.2017. http://www.pshp.fi/ fi-FI/Ohjeet/Hoitoketjut/Suuntima

Tenforde, M., Nowacki, A., Jain, A. \& Hickner, J. (2011). The Association Between Personal Health Record Use and Diabetes Quality Measures. Journal of General Internal Medicine, 27 (4), 420-424.

Tilastokeskus (2016). Suomalaiset käyttävät Internetiä yhä useammin. Luettu 20.2.2018 https://www. stat.fi/til/sutivi/2016/sutivi_2016_2016-12-09_ tie_001_fi.html

Tilastokeskus (2017). Liitetaulukko 9. Internetin käyttö ja käytön useus 2017, \%-osuus väestöstä. Luettu 6.4.2018. www.stat.fi/til/sutivi/2017/13/ sutivi_2017_13_2017-11-22_tau_009_fi.html

Timonen, O. (2004). Lääkärin etävastaanotto perusterveydenhuollossa. Satunnaistettu, kontrolloitu tutkimus videoneuvottelulaitteiston avulla toteutetus- ta etävastaanottokokeilusta. Väitöskirja, Oulun yliopisto, lääketieteellinen tiedekunta. Oulu University Press, Oulu.

Tutkimuseettinen neuvottelukunta (2012). Hyvä tieteellinen käytäntö ja sen loukkausepäilyjen käsitteleminen Suomessa. Helsinki: Tutkimuseettinen neuvottelukunta.

Valtioneuvosto (2018). Mikä on sote-uudistus? Luettu 11.11.2018.

https://alueuudistus.fi/mika-on-sote-uudistus

Velardo, C., Shah, S., Gibson, O., Clifford, G., Heneghan, C., Rutter, H., Farmer, A. \& Tarassenko, L. (2017). Digital health system fot personalised COPD long-term management. $B M C$ Medical Informatics and Decision Making, 17:19, $1-14$.

Virtuaalisairaala2.fi (2018). Laadukasta hoitoa kaikille asuinpaikasta riippumatta. Luettu 4.9.2018. http://www.virtuaalisairaala2.fi/fi/esittely/

Vivago.fi (2018). Vivago CARE -kello. Luettu 6.9.2018

https://www.vivago.fi/tuote/vivago-care-kello/

Volman, M. \& van Eck, E. (2001). Gender equity and information technology in education. The second decade. Review of Educational Research 71, 613-631.

Woods, S., Forsberg, C., Swartz, E., Nazi, K., Hibbard, J., Houston, T. \& Gerrity, M. (2017). The Assosiation of Patient Factors, Digital Access, and Online Behavior on Sustained Patient Portal Use: A Prospective Cohort of Enrolled Users. Journal of Medical Internet Research, Oct, 19(10), e345.

Zarcadoolas, C., Vaughon, W., Czaja, S. \& Rockoff, M. (2013). Consumer's perceptions of patient-accessible electronic medical records. Journal of Medical Internet Research, 15(8): e168.

Young, H. \& Nesbitt, T. (2017). Increasing the Capacity of Primary Care Through Enabling Technology. Journal of General Internal Medicine, Apr 32(4); 398-403. 